\title{
Distribution of nutrient elements and organic carbon in the lower reaches of the Selenga River
}

LIMNOLOGY FRESHWATER

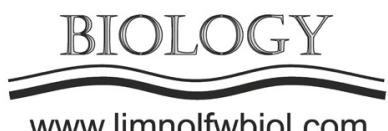

\author{
Denisova I.*, Efimova L., Sharapova E., Chalov S. \\ Lomonosov Moscow State University, Moscow
}

\begin{abstract}
The content of nutrient elements and organic carbon in the water of the lower course of the Selenga River and its long-term changes under the influence of natural and anthropogenic factors are considered. For analysis, data from field studies carried out in the summer of 2018 and 2019 was used, as well as long-term materials on the chemical composition of water in the closing section of the river (Kabansk gauging station).

Today, the hydroclimatic factor largely determines the chemical composition of water in the lower reaches of the Selenga. The aridization of the climate in the region and the associated decrease in the water content of the river led to a decrease in the dilution of diffuse and point pollution. During the period from 1980 to 2017, the average long-term concentrations of total phosphorus increased by 2 times and nitrates by 2.25 times. At the same time, the supply of silicon to Lake Baikal decreased by 1.7 times. Its concentration determines the growth of diatomaceous algae - the main producer of organic matter.

Climatic changes largely influence to the transformation of land use on the watershed of the lower reaches of the Selenga River. It was found that agricultural activity on the watershed increases the proportion of suspended form of chemical elements (in particular phosphorus and organic carbon). In the delta of the river, when hydrodynamic conditions change, suspension deposition is observed, the content of dissolved forms of nutrients and organic substances increases. In heated delta areas with low flow rates and intensification of production processes, the organic form of phosphorus prevails over mineral.
\end{abstract}

Keywords: Selenga watershed, lower reaches, nutrients, organic carbon, long-term fluctuations, water runoff, anthropogenic factor.

\section{Introduction}

The processes on the watershed of the lower reaches of the Selenga River are decisive for the state of Lake Baikal, and the river delta is a biogeochemical barrier where nutrient and organic substances brought by Selenga River are redistributed and accumulated. In the lower reaches, the river forms most of the flow from territories exposed to anthropogenic effects.

Despite a large number of works on the issues of water quality of the Selenga River (Sorokovikova et al., 2018; Domysheva et al., 2019), the contribution of climate change and the transformation of land use to the variability of the chemical composition of water has not been fully studied. The assessment of multiyear trends in the closed river section, supplemented by detailed field data, allows to consider trends in the transformation of water quality parameters at the quantitative level.

\section{Materials and methods}

Studies of long-term variability are based on data on the chemical composition of water in the lower reaches of the river Selenga (Kabansk gauging station) of the German portal GEMStat (The Global Freshwater Quality Database). To assess the spatial variability of nutrient and organic substances, the results of field studies carried out in August 2018 and 2019 as part of a comprehensive expedition of the Faculty of Geography of Moscow State University were used. Samples for determining nutrient elements were filtered through a membrane filter with a pore diameter of $0.45 \mu \mathrm{m}$ and frozen. The content of orthophosphates $\left(\mathrm{P}-\mathrm{PO}_{4}\right)$ and total phosphorus in filtered and unfiltered samples and the concentration of silicon were determined in the hydrochemical laboratory of Krasnisidovo Educational and Scientific Station of the Moscow State University (Analiticheskiye, kineticheskiyei raschetnyye metody..., 
2017). Dissolved organic carbon was determined on a Liqui TOC analyzer by high temperature catalytic oxidation. Suspended organic carbon was determined on a CHNS elemental analyzer at a temperature of up to $1150^{\circ}$.

The impact of the transformation of land use on the catchment of the lower reaches of Selenga was estimated from the Landsat space images of the MSS system (for 1980) and Landsat 8 (for 2015).

\section{Results and discussion}

An assessment of the annual average chemical composition of the water of the Selenga River over a long period revealed their relationship with climate and anthropogenic factors. The intensification of environmental management in the context of ongoing urbanization and a decrease in water content, contributes to an increase in the concentration of some hydrochemical indicators. There is a clear trend towards an increase in the average long-term content of total phosphorus and nitrates associated with the supply of municipal and agricultural effluents. The increase in total phosphorus concentration occurs due to an increase in its organic form.

Since the 20th century there has been a noticeable area reduction of arable land with their subsequent overgrowth; the role of pastures near settlements increased. This fact is confirmed by a decrease in the flow of suspended sediments of the main rivers.

The increase in turbidity to $200 \mathrm{mg} / \mathrm{l}$ of water was caused by an increase in the supply of suspended particles from the catchment due to the low resistance of soils and rocks to erosion, as well as under the influence of the agricultural factor, in which an increase in turbidity is observed in areas of plowing and grazing. The flood contributed to the additional entry of a suspended form of mineral phosphorus into the watercourses (up to $152 \mu \mathrm{g} / \mathrm{l}$ ).

In lower reaches of the River Selenga in 2019, mineral phosphorus prevailed due to the passage of the flood at that time, also high concentrations were observed near settlements where the flow of mineral phosphorus occurs as part of wastewater. In the delta, the organic form prevailed due to the consumption of mineral phosphorous by phytoplankton.

Increased concentrations of dissolved organic carbon can be caused by both the anthropogenic factor and the decomposition of primary products. The predominance of the suspended form of organic carbon occurs simultaneously with an increase in turbidity and flow rate as a result of which the mineral suspension particles do not have time to settle.

\section{Conclusion}

1. The hydroclimatic factor affected the average longterm decrease in the content of some substances: in conditions of prolonged low water (19962017), there was a decrease in the concentrations of suspended substances and silicon. When the aridization of a territory with a parallel decrease in water content caused a decrease in dilution of diffuse and point pollution, which led to an increase in the average annual concentrations of total phosphorus and nitrates.

2. The highest concentrations of total phosphorus in Selenga water were noted in the delta. The share of organic phosphorus prevails over mineral with the exception of the area above the delta, which is associated with the supply of municipal effluents of Ulan-Ude, and in the delta of the river - under the influence of production processes.

3. Hydrometeorological conditions change the relationship between phosphorus and organic carbon forms. During the summer rain flood, fine particles with high sorption capacity change the structure of transport of nutrient and organic substances, increasing the proportion of their suspended forms. In the delta of the Selenga River, the processes of suspension deposition are intensified, the content of their dissolved forms increases.

\section{Acknowledgements}

The work was carried out with the support of the RFFI project No. 17-29-05027 "Long-term variability in the river flow of water, sediments and chemicals to Lake Baikal."

\section{References}

Analiticheskiye, kineticheskiye i raschetnyye metody $\mathrm{v}$ gidrokhimicheskoy praktike [Analytical, kinetic and calculation methods in hydrochemical practice]. 2017. In: Losovik P.A., Efremenko N.A. (Eds.). Saint-Petersburg: Nestor-Istoriya. (in Russian)

Domysheva V.M., Sorokovikova L.M., Sinyukovich V.N. et al. 2019. Ionic composition of water in Lake Baikal, its tributaries, and the Angara River source during the modern period. Russian Meteorology and Hydrology 44: 687-694. DOI: $10.3103 /$ S1068373919100078

Sorokovikova L.M., Tomberg I.V., Sinyukovich V.N. et al. 2018. Silica input with waters of the Selenga River and its transformation in the water area of the Selenga shoal. In: International Conference "Freshwater Ecosystems - Key Problems", pp. 324-325.

The Global Freshwater Quality Database GEMStat [Electronic resource]. Access mode: https://gemstat.org. (Circulation date: 15.02.2020). 